\title{
MIKROORGANISME PENDEGRADASI TPH (TOTAL PETROLEUM HYDROCARBON) SEBAGAI AGEN BIOREMEDIASI TANAH TERCEMAR MINYAK BUMI (Review Article)
}

\author{
Prasetyo Handrianto \\ Dosen Akademi Farmasi Surabaya \\ Email: prasetyohandrianto@gmail.com
}

\begin{abstract}
Exploitation and exploration activities will produce sewage sludge and crude oil spills that cause pollution to the environment and upgrading to the environment, biology and soil chemistry. Monitoring of oil pollution conditions on the soil can be done by detection of all hydrocarbon components, or what is called the total petroleum hydrocarbon (TPH). According to its components, this total petroleum hydrocarbon (TPH) can be classified into 3 points, aliphatic, alicyclic, and aromatic. One of the biological efforts that can be used to overcome petroleum pollution is by using bioremediation technology. There are several methods in bioremediation, one of which is the biostimulation method, where the growth of the original hydrocarbon decomposers is stimulated by adding nutrients, oxygen, $\mathrm{pH}$ optimization and temperature. Hydrocarbonoclastic microorganisms have characteristic not possessed by other microorganisms, namely their ability to excrete hydroxylase enzymes, which are hydrocarbon oxidizing enzymes, so that these bacteria can degrade petroleum hydrocarbons. Biodegradation can be formed if there is a structural transformation so that cahnges in molecular integrity occur. This process is a series of enzymatic or biochemical reaction that require ideal environmental conditions with the growth and proliferation of microorganisms. Something that need to be known before remediation are pollutants (organic or inorganic), degraded/ not, dangerous/ not, how many pollutants pollute the soil, the ratio of carbon $(\mathrm{C})$, Nitrogen $(\mathrm{N})$, and phophorus (P), soil type, soil conditions (wet dry), and how long pollutants have been deposited in these locations
\end{abstract}

Keywords: TPH, Bioremediation, Soil

\section{PENDAHULUAN}

Semakin meningkatnya kebutuhan masyarakat akan minyak bumi dan gas mengakibatkan semakin meningkat pula upaya eksplorasi dan eksploitasi terhadap sumbersumber minyak bumi di Indonesia. Dalam aktifitas eksploitasi dan ekplorasi akan menghasilkan lumpur limbah dan tumpahantumpahan minyak mentah yang menyebabkan pencemaran terhadap lingkungan. Pencemaran tersebut akan mengakibatkan perubahan terhadap sifat fisik, biologi dan kimia tanah.
Pemantauan terhadap kondisi pencemaran minyak bumi pada tanah salah satunya dapat dilakukan dengan deteksi terhadap keseluruhan komponen hidrokarbon, biasa disebut dengan total petroleum hydrocarbon (TPH). Menurut Nugroho (2006) total petroleum hydrocarbon (TPH) ialah merupakan pengukuran konsentrasi pencemar hidrokarbon minyak bumi dalam tanah atau serta seluruh pencemar hidrokarbon minyak dalam suatu sampel tanah yang sering dinyatakan dalam satuan $\mathrm{mg}$ hidrokarbon/ $\mathrm{kg}$ 
tanah.

Menurut komponennya, total petroleum hydrocarbon (TPH) ini dapat di golongkan menjadi 3 yaitu, alifatik, alisiklik, dan aromatik. Senyawa aromatik dapat berupa poliaromatik dan monoaromatik. Komponen dari monoaromatik adalah benzene, toluene, ethylbenzena dan isomer xylem (Nugroho, 2006). Hidrokarbon monoaromatik merupakan komponen hidrokarbon dari minyak bumi yang dapat cepat menyebar ke lingkungan/ tanah karena sifatnya sangat mudah terlarut dalam air (Arafa, 2003). Selain tersusun oleh komponen hidrokarbon, minyak bumi juga mengandung komponen non-hidrokarbon. Komponen non-hidrokarbon dalam minyak bumi dapat berupa unsur-unsur logam berat. Dari semua logam berat yang terdapat dalam minyak bumi, beberapa logam berat tergolong berbahaya (Sudarmaji, 2006) seperti, merkuri $(\mathrm{Hg})$, kadmium $(\mathrm{Cd})$, argon $(\mathrm{Ag})$, timbal $(\mathrm{Pb})$, arsen (As), copper $(\mathrm{Cu})$, dan cromium $(\mathrm{Cr})$.

Pencemaran minyak bumi di tanah seperti ini merupakan ancaman yang serius bagi kesehatan manusia (Vidali, 2001). Minyak bumi yang mencemari tanah dapat mencapai lokasi air tanah, sumber air yang menyediakan air bagi kebutuhan domestik maupun industri sehingga akan menjadi masalah serius bagi daerah yang mengandalkan air tanah sebagai sumber utama kebutuhan air bersih atau air minum. Hidrokarbon dengan konsentrasi sangat rendah, dapat mempengaruhi bau dan rasa air tanah (Atalas dan Bartha 1997 dalam Nugroho, 2006).

Fenomena pencemaran minyak bumi sampai saat ini masih banyak terjadi di Indonesia. Salah satunya adalah kasus yang terjadi di daerah tambang Kadewan, Kabupaten Bojonegoro, Propinsi Jawa timur. Di daerah tambang Kadewan ini terdapat 2 aktifitas penambangan yaitu penambangan oleh PERTAMINA dan pertambangan secara tradisional. Pada pertambangan minyak secara tradisional, teknologi operasional yang digunakan masih minim, sehingga banyak terjadi ceceran atau tumpahan minyak, baik dari kegiatan penambangan, pengolahan, maupun pengangkutan. Tercecernya maupun tertumpahnya minyak bumi inilah yang semakin lama akan mengakibatkan terjadinya pencemaran yang serius dan meluas terhadap tanah di kawasan itu.

Salah satu upaya secara biologis yang dapat digunakan untuk mengatasi pencemaran minyak bumi tersebut adalah dengan menggunakan teknologi bioremediasi. Bioremediasi ini sering digunakan karena relatif murah, efektif, efisien dan ramah lingkungan (Alamri, 2009; Handrianto, 2012; Mariano et al., 2007; Nugroho, 2006). Meskipun bioremediasi ini merupakan teknologi yang efektif dalam upaya menangani pencemaran minyak bumi, namun untuk memastikan hasil akhirnya harus tetap dilakukan pemantauan seperti kadar TPH, BTX, dan beberapa logam berat yang tergolong berbahaya.

Terdapat beberapa metode dalam bioremediasi, salah satunya adalah metode biostimulasi, dimana pertumbuhan pengurai hidrokarbon asli dirangsang dengan cara menambahkan nutrien, oksigen, optimalisasi $\mathrm{pH}$ dan temperatur (Mariano et al., 2007). Beberapa penelitian tentang biostimulasi dengan penambahan nutrien sudah pernah dilakukan seperti penggunaan kotoran sapi, limbah media jamur, kotoran ungas (Ibiene et al., 2011); pupuk kotoran kuda (Cunningham dan Philp, 2000); NPK (Abdulsalam dan Omale, 2009; Cunningham dan Philp, 2000); Biokompos, urea (Aliyata dkk, 2011); dan pupuk organik (Munawar dkk, 2005).

\section{METODE DALAM TEKNOLOGI BIOREMEDIASI}

Terdapat tiga pendekatan yang dapat digunakan dalam bioremediasi tumpahan minyak yaitu (Handrianto, 2013):

1. Bioaugmentasi, dimana mikroorganisme 
pengurai ditambahkan untuk melengkapi populasi mikroba yang telah ada

2. Biostimulasi, dimana pertumbuhan pengurai hidrokarbon indigenous dirangsang dengan cara menambahkan nutrien dan/ atau mengubah habitat

3. Bioavailability yaitu dilakukan dengan cara meningkatkan akses mikroba terhadap substrat hidrokarbon.

Beberapa penelitian tentang biostimulasi dengan penambahan nutrient sudah pernah dilakukan seperti penggunaan kotoran sapi, limbah media jamur, kotoran unggas (Ibiene et al., 2011); pupuk kotoran kuda (Cunningham dan Philp, 2000); NPK (Abdulsalam dan Omale, 2009; Cunningham dan Philp, 2000); Biokompos, urea (Aliyata dkk, 2011); dan pupuk nutrien (Munawar dkk, 2005).

Metode biostimulasi dengan penambahan nutrien pada bioremediasi tumpahan minyak mentah mampu menstimulasi pertumbuhan mikroba tanah. Bioremediasi dengan nutrien ini dalam waktu tertentu mampu menurunkan konsentrasi minyak (Munawar dkk, 2005) sebab pertumbuhan mikroba alami pada tanah tercemar tersebut akan mendegradasi TPH tanah tercemar minyak bumi. Mikroorganisme membutuhkan unsur seperti nitrogen dan fosfor untuk menunjang kehidupan dan metabolismenya, namun jumlah nutrien dalam tanah tercemar minyak bumi umumnya terbatas sehingga menghambat proses degradasi minyak dalam tanah tersebut (Nugroho, 2006), oleh karena itu diperlukan penambahan nutrien.

\section{MIKROBA PENDEGRADASI HIDROKARBON}

Mikroorganisme yang banyak hidup dan berperan di lingkungan yang mengandung hidrokarbon adalah bakteri, sedangkan kehadiran jenis yang lain tidak terlalu dominan tetapi cukup berperan yaitu fungi, ragi, alga dan aktinomisetes. Bakteri dalam aktifitas hidupnya memerlukan molekul karbon sebagai salah satu sumber nutrisi dan energi untuk melakukan metabolisme dan perkembangbiakanya. Secara khusus, kelompok mikroorganisme yang mampu menggunakan sumber karbon yang berasal dari senyawa hidrokarbon disebut mikroorganisme hidrokarbonoklastik. Krakteristik mikroorganisme hidrokarbonoklastik yang tidak dimiliki oleh mikroorganisme lain adalah kemampuanya mengekskresikan enzim hidroksilase, yaitu enzim pengoksidasi hidrokarbon, sehingga bakteri ini mampu mendegradasi senyawa hidrokarbon minyak bumi dengan memotong rantai hidrokarbon tersebut menjadi lebih pendek (Nugroho, 2006).

Mikroba yang dapat memanfaatkan hidrokarbon tersebar luas di lingkungan dan mulai memperbanyak diri ketika berada dalam kondisi yang sesuai (Nugroho, 2006). Organisme alam, baik indigen atau eksogen (ditambahkan), adalah agen utama yang digunakan untuk bioremediasi (Prescott et al., 2002 dalam Chatterjee et al, 2008). Jenis mikroba yang digunakan pun dapat bervariasi, tergantung dari sifat kimia polutan, dan harus dipilih dengan hati-hati karena mikroba hanya bertahan dalam kisaran kontaminan yang terbatas (Prescott et al, 2002;. Dubey, 2004; dalam Chatterjee et al, 2008). 
Jurnal SainHealth Vol. 2 No. 2 Edisi September 2018

(C) Fakultas Ilmu Kesehatan Universitas Maarif Hasyim Latif Sidoarjo

p-ISSN : 2548-8333

e-ISSN : 2549-2586

Tabel 1. Beberapa mikroorganisme potensial pendegradasi bahan pencemar hidrokarbon

\begin{tabular}{|c|c|c|}
\hline Mikroorganisme & $\begin{array}{l}\text { Bahan pencemar } \\
\text { pada penelitian }\end{array}$ & Referensi \\
\hline Bacillus subtilis & $\begin{array}{l}\text { TPH (total petroleum } \\
\text { hydrocarbon) }\end{array}$ & $\begin{array}{l}\text { Abdussalam dan } \\
\text { Omale, } 2009\end{array}$ \\
\hline $\begin{array}{l}\text { Micrococcus varians, } \\
\text { Bacillus substillis, } \\
\text { Pseudomonas aeruginosa }\end{array}$ & Minyak mentah & $\begin{array}{l}\text { Ekpo dan Udofia, } \\
2008\end{array}$ \\
\hline $\begin{array}{l}\text { Ochrobactrum anthropic, Stretophomonas, } \\
\text { Bacillus cereus }\end{array}$ & $\begin{array}{l}\text { TPH (total petroleum } \\
\text { hydrocarbon) }\end{array}$ & Mariano et al., 2007 \\
\hline $\begin{array}{l}\text { Pseudomonas fluorescens, } \\
\text { Pseudomonas aeruginosa, } \\
\text { Bacillus subtilis, } \\
\text { Bacillus } \mathrm{sp} . \\
\text { Alcaligenes } \mathrm{sp} . \\
\text { Acinetobacter lwoffi, } \\
\text { Flavobacterium } \mathrm{sp} . \\
\text { Micococus roseous } \\
\text { Corinebacterium } \mathrm{sp} .\end{array}$ & $\begin{array}{l}\text { Petroleum } \\
\text { hydrocarbon }\end{array}$ & $\begin{array}{l}\text { Adebusoye et al., } \\
2007 \text { dalam Das dan } \\
\text { Chandran, } 2010\end{array}$ \\
\hline $\begin{array}{l}\text { Acinetobacter faecalis-type II } \\
\text { Pseudomonas cepacea } \\
\text { Actinobacillus sp. } \\
\text { Pseudomonas stutzeri } \\
\text { Pseudomonas pseudomallei } \\
\text { Pseudomonas fluorescens-25 } \\
\text { Pseudomonas aeruginosa } \\
\text { Rhodotorulla mucilaginosa } \\
\text { Candida parapsilosis }\end{array}$ & $\begin{array}{l}\text { Minyak mentah } \\
\text { (Sampel dari } \\
\text { Bojonegoro) }\end{array}$ & $\begin{array}{c}\text { Ni'matuzahroh dkk., } \\
2009\end{array}$ \\
\hline $\begin{array}{l}\text { Aeromonas hydrophila, } \\
\text { Pseudomonas putida, } \\
\text { Pseudomonas aeromonas, } \\
\text { Flavobacterium meningosepticum }\end{array}$ & $\begin{array}{l}\text { Minyak mentah } \\
\text { (Kilang minyak } \\
\text { Pertamina) }\end{array}$ & \\
\hline
\end{tabular}

Pada tabel 1 di atas spesies-spesies yang diisolasi oleh Ni'matuzahroh dkk. (2009) adalah berasal dari tanah tercemar minyak bumi di daerah tambang tradisional Bojonegoro. Dari 9 spesies yang berhasil diisolasi tersebut dapat menggambarkan bahwa tanah tercemar minyak bumi di daerah tambang tradisional Bojonegoro memiliki keanekarangaman yang cukup tinggi. Hal ini merupakan salah satu faktor yang memungkinkan untuk dilakukan biostimulasi untuk memaksimalkan pertumbuhan bakteri indigen tersebut.

\section{MEKANISME BIODEGRADASI HIDROKARBON}

Secara umum biodegradasi atau penguraian bahan (senyawa) organik oleh mikroorganisme dapat terjadi bila terjadi transformasi struktur sehingga terjadi perubahan integritas molekuler. Proses ini berupa rangkaian reaksi kimia enzimatik atau 
biokimia yang mutlak memerlukan kondisi lingkungan yang sesuai dengan pertumbuhan dan perkembangbiakan mikroorganisme (Shechan dalam Nugroho, 2006). Senyawa hidrokarbon dalam minyak bumi merupakan sumber karbon bagi pertumbuhan mikroorganisme, sehingga senyawa tersebut dapat didegradasi dengan baik (Nugroho, 2006). Ilustrasi dari mekanisme degradasi hidrokarbon secara aerob adalah sebagai berikut.

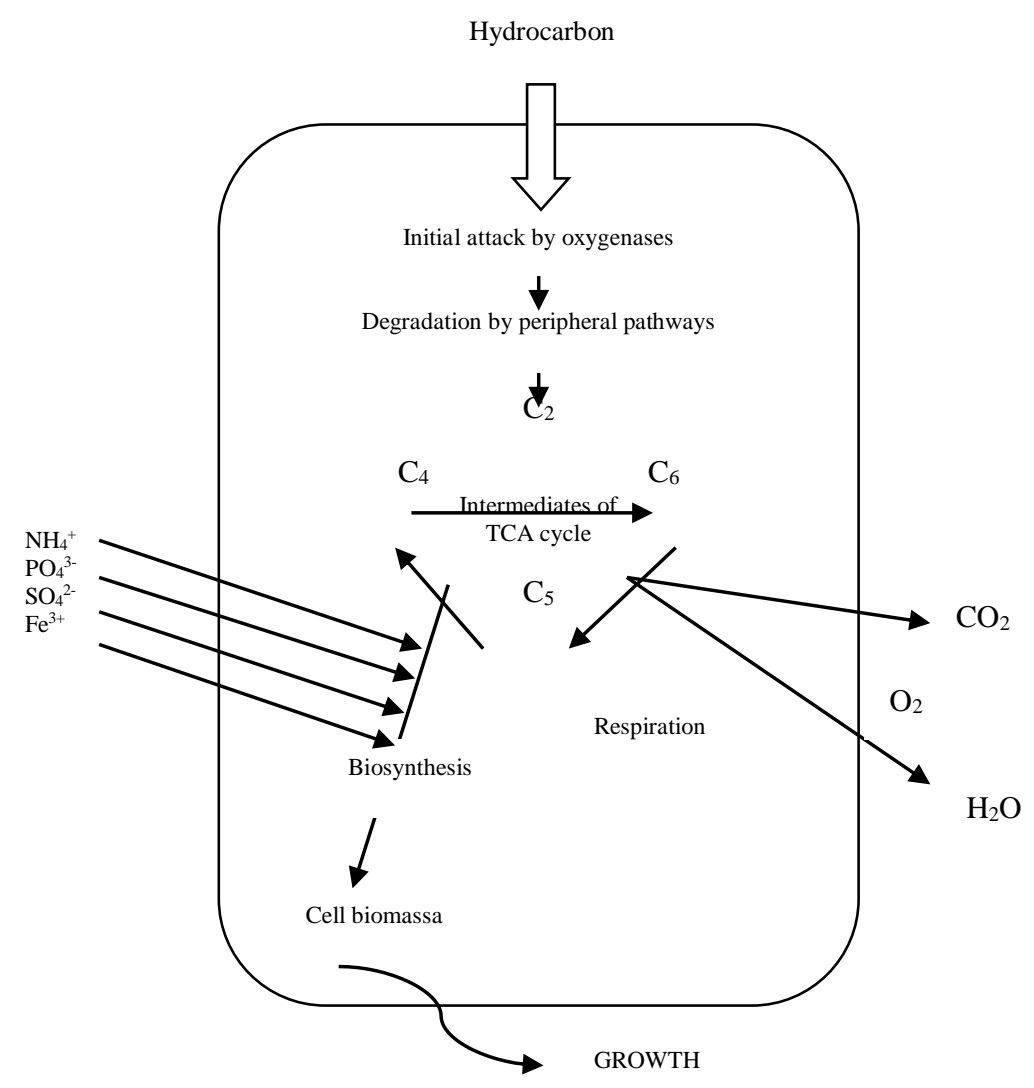

Gambar 1. Metabolisme hidrokarbon dalam kondisi aerob oleh bakteri (Das dan Chandran, 2010)

Di dalam minyak bumi terdapat dua macam komponen yang dibagi berdasarkan kemampuan mikroorganisme menguraikannya, yaitu komponen minyak bumi yang mudah diuraikan oleh mikroorganisme dan komponen yang sulit didegradasi oleh mikroorganisme. Komponen minyak bumi yang mudah didegradasi oleh bakteri merupakan komponen terbesar dalam minyak bumi atau mendominasi, yaitu alkana yang bersifat lebih mudah larut dalam air dan terdifusi ke dalam membran sel bakteri. Jumlah bakteri yang mendegradasi komponen ini relatif banyak karena substratnya yang melimpah di dalam minyak bumi. Isolat bakteri pendegradasi komponen minyak bumi ini biasanya merupakan pengoksidasi alkana normal. Komponen minyak bumi yang sulit didegradasi merupakan komponen yang jumlahnya lebih kecil dibanding komponen yang mudah didegradasi. Hal ini menyebabkan bekteri pendegradasi komponen ini berjumlah lebih sedikit dan tumbuh lebih lambat karena kalah bersaing dengan pendegradasi alkana yang memiliki substrat lebih banyak. Isolasi bakteri ini biasanya memanfaatkan komponen 
Jurnal SainHealth Vol. 2 No. 2 Edisi September 2018

(c) Fakultas Ilmu Kesehatan Universitas Maarif Hasyim Latif Sidoarjo

p-ISSN : 2548-8333

e-ISSN : 2549-2586

minyak bumi yang masih ada setelah pertumbuhan lengkap bakteri pendegradasi komponen minyak bumi yang mudah didegradasi.

\section{FAKTOR YANG MEMPENGARUHI BIOREMEDIASI}

Sebelum melakukan remediasi, hal yang perlu diketahui:

1. Jenis pencemar (organik atau anorganik), terdegradasi/tidak,berbahaya/tidak

2. Berapa banyak zat pencemar yang telah mencemari tanah tersebut

3. Perbandingan karbon $(\mathrm{C})$, nitrogen $(\mathrm{N})$, dan fosfor $(\mathrm{P})$

4. Jenis tanah .

5. Kondisi tanah (basah, kering)

6. Telah berapa lama zat pencemar terendapkan di lokasi tersebut,kondisi pencemaran (sangat penting untuk dibersihkan segera/ bisa ditunda). Terdapat beberapa faktor yang mempengaruhi efektifitas bioremediasi diantaranya adalah keanekaragaman jenis mikroorganisme yang ada, ketersediaan kontaminan untuk didegradasi oleh mikroba, kondisi lingkungan, konsentrasi dan toksisitas bahan pencemar. Bioremediasi membantu mikroorganisme tumbuh dan meningkatkan populasi mikroba dengan menciptakan kondisi lingkungan yang optimum sehingga dapat mendetoksifikasi dengan jumlah dan kecepatan maksimum. Proses ini disebut dengan biostimulasi. Biostimulasi salah satunya adalah dengan cara penambahan nutrien untuk membantu meningkatkan metabolisme mikroba indigenous. Selain aspek nutrien, beberapa faktor lingkungan lainnya juga berperan dalam mengoptimalkan degradasi terhadap kontaminan. Kondisi lingkungan optimum yang yang dibutuhkan untuk mendegradasi kontaminan adalah sebagai berikut.

Tabel 2.Kondisi lingkungan yang mempengaruhi degradasi (Vidali, 2001)

\begin{tabular}{|c|c|c|}
\hline Parameter & $\begin{array}{c}\text { Kondisi yang disyaratkan } \\
\text { untuk aktifitas } \\
\text { mikroorganisme }\end{array}$ & $\begin{array}{l}\text { Titik optimum untuk } \\
\text { degradasi minyak bumi }\end{array}$ \\
\hline Kelembaban tanah & $25-28 \%$ & $30-90 \%$ \\
\hline $\mathrm{pH}$ tanah & $5,5-8,8$ & $6,5-8,0$ \\
\hline Kadungan oksigen & Aerobik & $10-40 \%$ \\
\hline Kandungan nutrien & $\begin{array}{l}\mathrm{N} \text { dan } \mathrm{P} \text { untuk pertumbuhan } \\
\text { mikroorganisme }\end{array}$ & $\mathrm{C}: \mathrm{N}: \mathrm{P}=100: 10: 1$ \\
\hline Temperatur $\left({ }^{\circ} \mathrm{C}\right)$ & $15-45$ & $20-30$ \\
\hline Kontaminan & Tidak terlalu toksik & $\begin{array}{l}\text { Hidrokarbon } 5-10 \% \text { dari berat } \\
\text { kering tanah }\end{array}$ \\
\hline Logamberat & $2000 \mathrm{ppm}$ & $700 \mathrm{ppm}$ \\
\hline Komposisi tanah & $\begin{array}{c}\text { Rendah tanah liat atau } \\
\text { kandungan lumpur }\end{array}$ & - \\
\hline
\end{tabular}

\section{DAFTAR PUSTAKA}

Alami, Nur Hidayah. 2010. Efektivitas biosurfaktan
putidaT1(8) dalam bioremediasi tanah tercemar minyak mentah. Tesis, Universitas Airlangga, Surabaya 
Jurnal SainHealth Vol. 2 No. 2 Edisi September 2018

(c) Fakultas Ilmu Kesehatan Universitas Maarif Hasyim Latif Sidoarjo

p-ISSN : 2548-8333

e-ISSN : 2549-2586

Abdusssalam dan Omale. 2009.Comparation of biostimulation and bio augmentation techniques for the remediation of used motor oil contaminated soil. Braz. Arch. Biol. Technol. Vol.52 no.3

Aliyata, Barokah, La Ode Sumarlin, Ahmad Saepul Mujab. 2011. Penggunaan biokompos dalam bioremediasi lahan tercemar limbah minyak bumi. Valensi. vol.2 no.3

Arafa, A.M., 2003. Biodegradation of some aromatic hydrocarbons (BTEX) by a bacterial consortium isolated from polluted sait in Saudi Arabia. Pakistan Journal of Biological science 17: 1482-1486.

Chatterjee, Sandipan et al. 2008.Bioremediation: a tool for cleaning polluted environments (Review Paper).Journal of Applied Biosciences. Vol. 11: 594 - 601.

Cunningham dan Philp. 2000. Comparation of bioaugmentation and biostimulation in ex situ treatment of diesel contaminated soil. Land Contamination and Reclamation. 8 (4)

Das, Nilanjama dan Preethy Chandran. 2011. Microbial degradation of petroleum hydrokarbon contaminant: An Overview. Biotechnology Research International. V.2011 (Article id.941810).

Ekpo, M.A. dan U.S. Udofia. Rate of biodegradation of crude oil by micoorganims isolated from oil sludge environment. African Journal Of Biotechnology. Vol.7 (24), pp
4495-4499.

Ibiene et al., 2011. Bioremediation of hydrocarbon contaminated soil in the Niger delta using spent mushroom compost and other organic waste. Nigerian Journal of Agriculture, Food And Environment. 7(3)

Mariano A.P., Ana Paula, Dejanira de Franceschi, and Daniel Marcos Bonotto, 2007. Laboratory study on the bioremediation of diesek oil contaminated soil from petrol station. Brazillian Jaournal of Microbiology. 38: 346-353.

Munawar dan Tini Surtiningsih. 2005. Bioremediasi Tumpahan Minyak Mentah Dengan Metode Biostimulasi Di Lingkungan Pantai Surabaya Timur. JurnalHayati.105-132.

Ni'matuzahroh, fatimah, Rini Purbowati, Ahmad thontowi, Agus supriyanto, dan M. Afandi. 2009. Exploration of polyaromatic hydrocarbonoclastic microbes from oil polluted soil. Proceeding: Congress and international conference of indonesian society for microbiology.

Nugroho, A. 2003. Bioremidiasi Hidrokarbon Minyak Bumi. Jakarta: Bumi Aksara

Handrianto, P. (2012). Teknologi bioremediasi dalam mengatasi tanah tercemar hidrokarbon. In Prosiding Seminar Nasional Kimia Unesa 2012 (pp. 2230).

Handrianto, P. (2013). Bioremediasi tanah tercemar minyak bumi di lokasi pertambangan tradisional Bojonegoro dengan metode stimulasi 
Jurnal SainHealth Vol. 2 No. 2 Edisi September 2018

(C) Fakultas Ilmu Kesehatan Universitas Maarif Hasyim Latif Sidoarjo

p-ISSN : 2548-8333

e-ISSN : 2549-2586

menggunakan kotoran sapi (Doctoral

Dissertation, Universitas Airlangga).

Sudarmaji, J. Mukono, dan Corie I.P. 2006.

Toksikologi logam berat B3 dan

dampaknya terhadap kesehatan. FKM.

Universitas Airlangga.

Vidali, M., 2001. Bioremediation. An over view. Pure Appl.Chem. 73(7): 11631172 . 